\title{
ON JEWISH PARTIES \\ AND YOUTH MOVEMENTS
}

A gamut of ideologies emerged in Jewish society in Eastern Europe from the end of the nineteenth century, resulting in several political parties, active in Jewish political life in Poland in the interwar period. There were also many youth movements, some affiliated with parties, others not. Since these movements were such a vital part of the resistance organizations in the ghettoes, we present here a brief outline of the spectrum, moving from left to right:

1. The illegal Communist Party.

2. The Bund - short for "General Jewish Workers' Union." A strong Jewish socialist-democratic party, founded in 1897, which advocated Yiddish language and culture and secular Jewish nationalism in the Diaspora (Doyigkeyt_-"Hereness"); opposed to Zionism.

3. Po'alei Zion Left-a small left-Marxist Zionist party, sympathizing with the Soviet Union, but not accepted by the Communist Party. Supported the Yiddish language, even in Eretz Israel.

4. He-Halutz-an umbrella organization which included the following Zionist youth movements (along with several smaller ones) which aimed at personal realization through building kibbutzim in Israel:

A. Ha-Shomer Ha-Tza'ir-“"Young Guard." A Marxist-Freudian Zionist youth movement, demanding personal realization at the age of eighteen by immigration to a kibbutz in Eretz Israel; hence it had no political party. It attracted members from the upper economic strata and the intellectual youth; was oriented to Polish and Hebrew, not Yiddish. 
B. He-Halutz Ha-Tza'ir_-"Young Pioneer." Frayhayt (Dror)_-"Freedom."

Zionist-socialist youth movements affiliated with the social-democratic Zionist Party Po'alei Zion (Z.S.) and HaKibbutz Ha-Meuchad kibbutz movement in Israel. Whereas Frayhayt was more Yiddish-oriented and appealed to the masses, He-Halutz appealed to youth in the Gymnasia and promoted Hebrew. These two movements united before the outbreak of World War II in 1939 under the name DrorHe-Halutz Ha-Tza'ir, but tensions remained between the youth movement which advocated Aliya to Eretz Israel at the age of 18 on the one hand, and the party which was content to be Zionist in Poland, on the other.

C. Gordonia-A non-Marxist socialist youth movement promoting Aliya to a kibbutz in Israel.

5. Two General Zionist parties, one liberal and one conservative, and the youth movement, $\mathrm{Ha}$-Oved $\mathrm{Ha}$-Tzioni ("Zionist Work").

6. Two religious parties: the Zionist Mizrakhi and the anti-Zionist Agudas Yisroel, and their respective youth movements.

7. The radical rightist Revisionist party, which split from the World Zionist Organization, and its paramilitary youth movement Betar. 